\title{
Comparative Analysis between Biogas Flow in Landfill and Electrical Resistivity Tomography in Rio Claro City, Brazil
}

\author{
César Moreira, Marcus Castro, Ana Gonsalez, Fernanda Cavallari, \\ Thais Munhoz, and Alice Pereira
}

Universidade Estadual Paulista, UNESP, Avenue 24-A, 1515, 13506-900 Rio Claro, SP, Brazil

Correspondence should be addressed to César Moreira; moreirac@rc.unesp.br

Received 10 June 2014; Accepted 19 August 2014; Published 26 November 2014

Academic Editor: Umberta Tinivella

Copyright (C) 2014 César Moreira et al. This is an open access article distributed under the Creative Commons Attribution License, which permits unrestricted use, distribution, and reproduction in any medium, provided the original work is properly cited.

\begin{abstract}
The biogas originated from anaerobic degradation of organic matter in landfills consists basically in $\mathrm{CH}_{4}, \mathrm{CO}_{2}$, and $\mathrm{H}_{2} \mathrm{O}$. The landfills represent an important depository of organic matter with high energetic potential in Brazil, although with inexpressive use in the present. The estimation of production of the productive rate of biogas represents one of the major difficulties of technical order to the planning of capture system for rational consumption of this resource. The applied geophysics consists in a set of methods and techniques with wide use in environmental and hydrogeological studies. The DC resistivity method is largely applied in environmental diagnosis of the contamination in soil and groundwater, due to the contrast of electrical properties frequent between contaminated areas and the natural environment. This paper aims to evaluate eventual relationships between biogas flows quantified in drains located in the landfill, with characteristic patterns of electrical resistivity in depth. The drain of higher flow $\left(117 \mathrm{~m}^{3} / \mathrm{h}\right)$ in depth was characterized for values between $8000 \Omega \cdot \mathrm{m}$ and $100.000 \Omega \cdot \mathrm{m}$, in contrast with values below $2000 \Omega \cdot \mathrm{m}$, which characterize in subsurface the drain with less flow $\left(37 \mathrm{~m}^{3} / \mathrm{h}\right)$, besides intermediary flow and electrical resistivity values, attributed to the predominance of areas with accumulation or generation of biogas.
\end{abstract}

\section{Introduction}

The use of renewable resources as a source of clean and sustainable energy is increasingly gaining importance in the national and international levels, facing a reality of increasing global warming and its consequences, as a result of the intensification of anthropogenic carbon emissions in generating electrical energy, as what occurs with thermal coal plants.

Biogas is a gas mixture resulting from the anaerobic degradation of organic material of solid waste deposited in landfills and industrial effluents and domestic sewage treated by the anaerobic process. This compound has great potential for energy use in national terms, in a scenario where landfills have significant relevance, as depository of large amounts of organic matter [1].

Among the main methodologies to estimate the volume of biogas production in projects for energy recovery, it is noteworthy to mention the proposal of the Intergovernmental Panel on Climate Change [2], for state or national scenarios, or that one proposed by the U.S. Environmental Protection Agency [3] to plants for treatment or storage of waste. Other theoretical methods are found in [4-6]. A comparative analysis of these methodologies is performed in [7], which considered them as an inadequate study in generation from landfill, because of the use of preestablished default values or simply disregarding important factors such as the potential for methane generation of the waste and the production rate of the biogas.

According to [8] the mathematical models internationally used to estimate the methane generations in landfills do not satisfactorily cover specific conditions of climate and waste found in Brazil. The high amount of organic matter and the biodegradability of household waste generated in Brazil, associated with favorable climatic conditions such as high temperature and rainfall, intensify the process of gas generation in the early years, with depletion of the process in a short period when compared to countries of cold climate. The combination of climate and biodegradation results in a singular synergism that limits the safe application 
of mathematical models currently available, the use of which requires the proposition of indicating parameters for stages of degradation of organic matter and biological activity.

The geophysics makes up a set of indirect methods of investigation, some of which are sensitive to the physical properties characteristic to areas of accumulation of gases in the subsurface. The DC resistivity method is widely used in studies of environmental diagnosis in cases such as investigations of contaminants in soil and groundwater originated from industrial or commercial activities $[9,10]$, vulnerability to input of pollutants in aquifers [11-13], and characterization of subsurface in sanitary landfills [14-16].

The characteristic signature of liquid contaminants enriched in salts, like necroleachate arising from the decomposition of cadavers or the leachate from the decomposition of organic waste, is the low electrical resistivity, in contrast with rocks and minerals that make up the geological environment.

In the work of [17] the resistivity method is applied in the landfill of Cordeirópolis (Brazil), combined with measurements of $\mathrm{pH}$ and Eh. The operating procedure of the landfill consists of trenching, dumping waste, covering with excavation soil, and recording of the closing dates. Measures of low resistivity were associated with concentrations of leachate. Correlations between geochemical parameters, values of electrical resistivity, and closing age of the ditches allowed estimating the predominant phases of organic matter degradation.

In [18] the evaluation of DC resistivity measurements is proposed for estimating emission rates of $\mathrm{CH}_{4}$ and $\mathrm{CO}_{2}$ in the Pera Galini landfill (Greece), through the technique of electrical tracking, in areas with varying degrees of gaseous emission quantified in the study. The results enabled us to distinguish areas with varying degrees of flow through by means of electrical resistivity patterns, besides allowing evaluating and estimating the high potential for biogas production from a significantly reduced point amount of specific measures of gaseous emission. The conclusion is that the electrical resistivity is a vital tool to estimate the emission of biogas in landfills, at an effectively smaller cost and with high accuracy when compared to traditional procedures, although it not distinguishing the types of constituent gases.

Although there are many studies that describe the use of geophysical methods in the environmental diagnosis of landfills, most of these works mainly aim at the characterization of the area with percolation of leachate. However, there are few studies aimed at determining relationships between electrical resistivity, natural electrical potential, and biological and physicochemical processes and their relationship to the production of leachate and biogas in landfills $[17,19]$.

In this sense, the present study assesses the potential for application of the DC resistivity method as a tool for characterization of areas with accumulation of biogas, by means of measurements of electrical resistivity in unsaturated layers of waste and crossing them with direct measurements of the biogas flow, in a cell of deactivated waste, at the landfill in the municipality of Rio Claro, Brazilian southern.

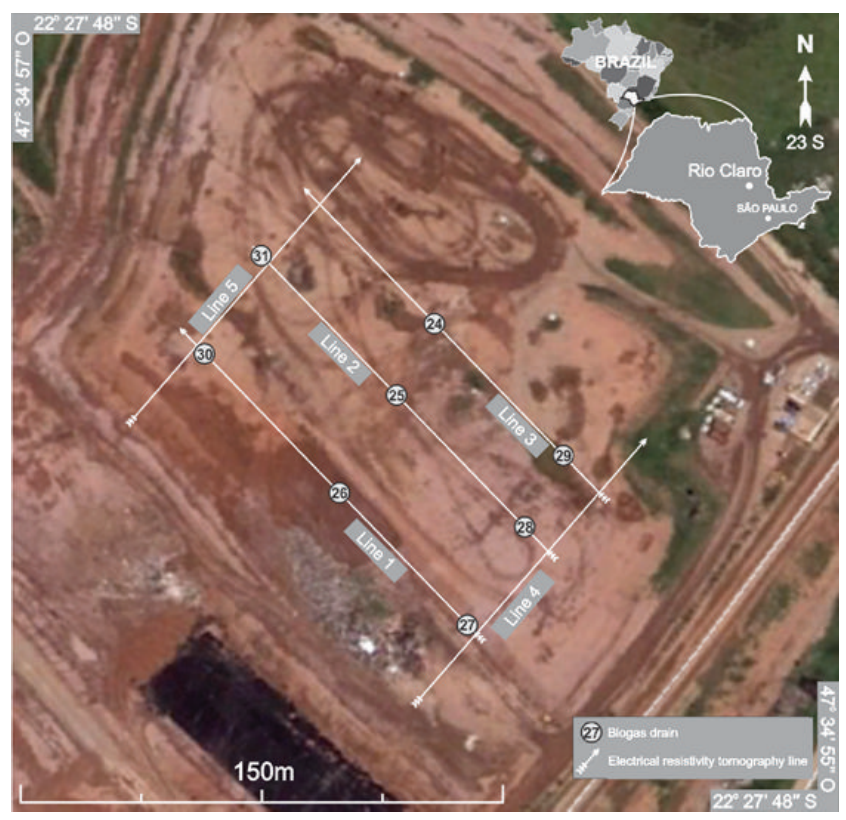

FIGURE 1: Location of the area of studies with position of the lines of data acquisition and drains for measuring the flow of biogas.

\section{Area of Studies}

The area of studies consists of landfill of solids residues of the municipality of Rio Claro, São Paulo State, Brazil, distant about $180 \mathrm{~km}$ from the state capital (Figure 1). The beginning of activities dates from 2001, in an area of approximately $98,000 \mathrm{~m}^{2}$ destined for disposal of solid waste, with a daily average of 190 tons and a monthly average of 5,000 tons. In July 2012 the landfill was expanded by the installation of a new cell, currently in use (Figure 2).

The area presents a relief with gentle slope and descending towards the northeast, consisting of sandy soils and sandy clay soils produced by alteration of sandstones belonging to the Rio Claro Formation, covered by siltstones and mudstones gathered in Corumbataí Formation.

The construction scheme of the landfill comprises the local topography and consists of opening individual cells, $200 \mathrm{~m}$ long and $50 \mathrm{~m}$ wide, for the excavation of rock types from Rio Claro Formation and from the top of Corumbataí Formation from northeast to southeast direction, followed by basal cuttings and installing of gradients of about $1 \%$ to northeast. The landfill has basal and side impermeabilization sealing with a blanket of HDPE $2 \mathrm{~mm}$ thickness. A network to collect and drain the leachate leads the flow by gravity to the terminal boxes and then to aeration lagoons for treatment.

The waste is dumped directly into cells by tipper trucks of urban collecting, later leveled to horizontal landings by action of bulldozers, daily covered by soil/sediment stored after excavation of the cell (Figure 2(a)). At this stage, vertical drains are installed for plumbing and atmospheric dissipation of biogas generated by the decomposition process of organic matter in waste, constantly alternated as new levels are built.

The final level is covered by a layer of about $1 \mathrm{~m}$ of soil/clay pellet, with a drop of $2 \%$ for surface water runoff 


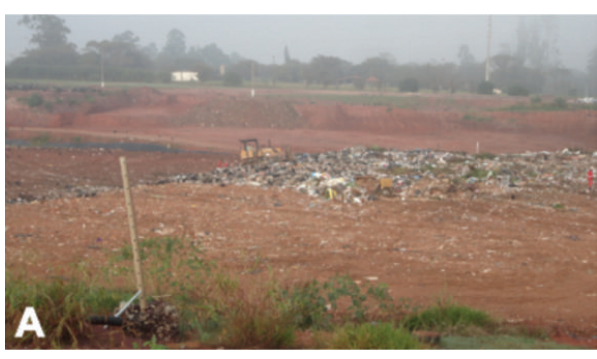

(a)

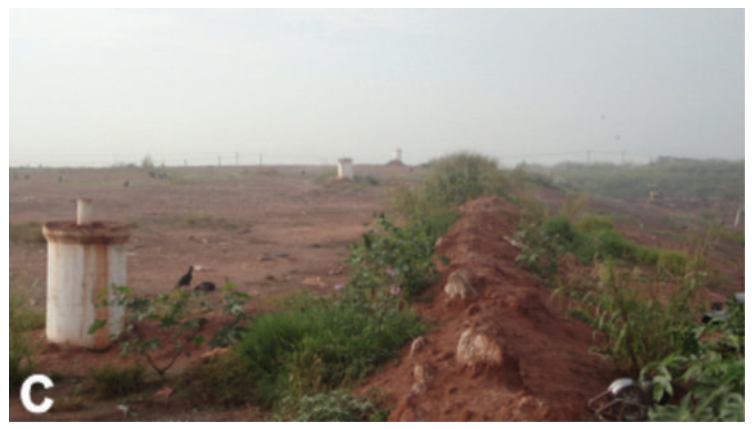

(c)

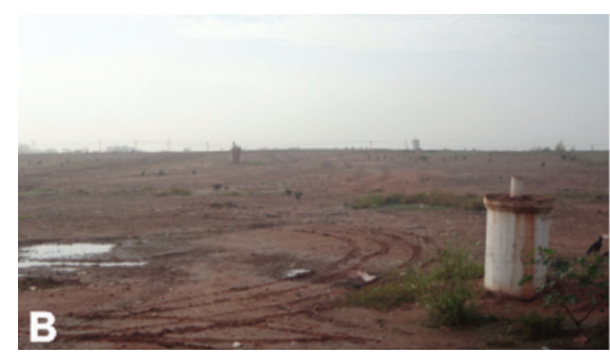

(b)

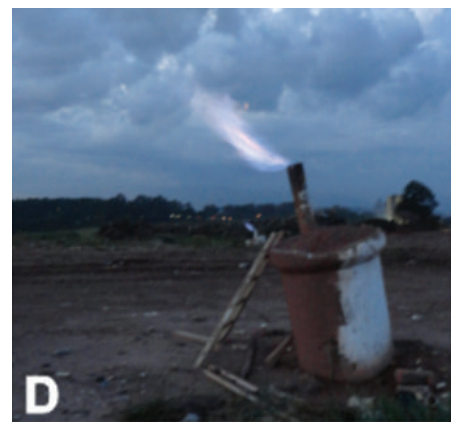

(d)

Figure 2: (a) Waste disposal in active cell. (b) Partial view of studied cell. (c) Guidance of drains crossed by line 2. (d) Drain number 28 with burning of biogas.

(Figure 2(b)). Dikes marginal to the limits of the upper level are built, to direct the flow of rainwater by laminar flow and attenuation processes of lateral erosion (Figure 2(c)). Drains are finalized by steel tubes coated by concrete pipes for burning biogas and dissipation of the generated heat (Figure 2(d)). Drains are constantly lit for consumption of the biogas by burning in an attempt to prevent accumulation in large scale and minimize the risk of explosion.

According to [20] the degradation of organic material in landfills passes through five stages.

In phase 1 starts the microbiological activity in a landfill, where moisture favors the degradation reactions of organic matter by aerobic mean. Phase 2 is transitional, with transition to anaerobic condition. In phase 3 occurs the formation of acids, with predominance of total volatile acids, decrease in $\mathrm{pH}$, increase in chemical oxygen demand (COD) in the leachate, and increased ionic species. In step 4 (methanogenic fermentation) occur the highest production of methane $\left(\mathrm{CH}_{4}\right)$ and carbon dioxide $\left(\mathrm{CO}_{2}\right)$, increase of $\mathrm{pH}$, and reduction in the formation of leachate. Phase 5 is the final maturation where nutrients are scarce.

The factors that influence the rate of generation of biogas, according to [3], are as follows.

(i) Waste composition: the higher the percentage of organic material in the waste, the greater the potential for methane generation.

(ii) Oxygen concentration: the organic material must be decomposed into oxygen-free environment; this way, it is possible to cover the waste with soil or with the residue itself, creating anaerobic conditions in the lower layers of the landfill. (iii) $\mathrm{pH}$ : the methanogenic bacteria achieve greater productivity with $\mathrm{pH}$ between 6.8 and 7.2. In the initial phase, landfills present acid $\mathrm{pH}$, which tends to approach neutrality from the methanogenic phase.

(iv) Temperature: the ideal temperature for anaerobic digestion is between $29^{\circ} \mathrm{C}$ and $38^{\circ} \mathrm{C}$ for mesophilic bacteria and between $49^{\circ} \mathrm{C}$ and $70^{\circ} \mathrm{C}$ for thermophilic ones. Below $10^{\circ} \mathrm{C}$ there is a sharp drop in the rate of generation of methane gas. Typically, the decomposition itself provides sufficient time for the heat methanogenesis to occur.

(v) Humidity: it is essential to the life of decomposing bacteria. A high humidity, approximately $60 \%$ by weight, increases the generation of biogas.

Relevant aspects in generating biogas at landfills are represented by forms of packaging waste and operational procedures, content of organic matter in the overall composition of the residue, which can stimulate anaerobic processes. The moisture content is something crucial to the development and metabolism of bacteria, such as agent to transport the nutrients and as a facilitator for colonization of new areas within the landfill scope. These factors, combined with physicochemical conditions, temperature, and access to nutrients, influence directly the survival of microorganisms and biogas generation [1].

The understanding of the genesis of biogas enables some important considerations on the action of processes of anaerobic degradation of organic matter and their effects on physical properties change in the mass of waste. 
Biogeochemical reactions are initiated immediately after the coverage of waste in landfills. Organic compounds are oxidized in aerobic processes in shallow locations where aeration is by contribution of atmospheric oxygen or infiltration of rainwater, similar to combustion reactions, generating $\mathrm{CO}_{2}$ and water vapor, both quickly dissipated.

However, the effect of chemical and biological processes is enhanced by anaerobic digestion in three main stages [21].

At first there occurs hydrolysis of complex organic matter by the action of fermentative bacteria in soluble molecules. Then, these molecules are converted into simple organic acids such as acetic acid, propionic acid, butyric acid, and ethanol, besides $\mathrm{CO}_{2}$ and $\mathrm{H}_{2}$. In the third stage the generation of $\mathrm{CH}_{4}$ by methanogenic bacteria by breaking acids in $\mathrm{CH}_{4}$ and $\mathrm{CO}_{2}$ or by the reduction of $\mathrm{CO}_{2}$ and $\mathrm{H}_{2}$ occurs.

This exothermic reaction for anaerobic decomposition releases a small amount of heat and produces a gas with average levels of $54 \% \mathrm{CH}_{4}$ and $46 \% \mathrm{CO}_{2}$. The biogas produced in landfills also contains water vapor near the saturation point and small amounts of $\mathrm{NH}_{4}, \mathrm{H}_{2}, \mathrm{H}_{2} \mathrm{~S}$, and other minor constituents.

\section{Materials and Methods}

The biogas flow comes from the work of [22], determined from velocity measurements of gases in the drains, with the aid of a galvanized pipe with standard diameter of $100 \mathrm{~mm}$ and a digital thermal anemometer with an accuracy of $0.01 \mathrm{~m} / \mathrm{s}$, in the range of measurements between $0 \mathrm{~m} / \mathrm{s}$ and $10 \mathrm{~m} / \mathrm{s}$.

The procedure initially involved extinguishing the combustion of biogas at the end of the drain hose, coupling of the galvanized pipe to canalize the biogas, and introduction of a telescopic handle of the thermoanemometer into a side hole of the tube, located $1 \mathrm{~m}$ from its upper extremity [22]. This routine was adopted for the protection of the measurement probe from the influences of wind or any air movement that could exert influence on the measurements of biogas velocity, besides standardizing a piping with a single diameter for flow calculation.

Then, DC resistivity method was applied for geophysical acquisition data, which uses electrodes fixed on the surface of the ground, connected to the measuring instrument via a cable assembly $[23,24]$.

This instrument enables the injection of electrical current into the ground and taking measurements of potential difference produced by the interaction with the materials in depth. The electric potential produced in this interaction is captured by receiving electrodes and quantified. Applying Ohm's Law considering the spacing between electrodes, represented by a factor called $K$, allows for the calculation of the apparent resistivity parameter $(\rho a)$ for various levels of depth.

The resistivity parameter depends on the nature and the physical state of the material analyzed. The resistivity and electrical conductivity are related to the mechanisms of propagation of electrical current of the materials, conditioned in geological materials to processes of electronic or electrolyte activity [25]. The first occurs associated with the presence of metallic minerals or conductors, while the second occurs due to movement of ions dissolved in the water contained in the pores or cracks.

For disposition and movement of electrodes on the surface, the Wenner-Schlumberger electrical profiling technique arrangement was adopted, which consist in the alignment of a series of electrodes and the selection of four electrodes on each measure, where a pair of external electrodes is used for transmission of current (in Amperes) and the other internal pair is used for readings of tension (in Volts).

The lateral movement of this device along with the constant distancing of the pair of current electrodes with respect to the pair of tension electrodes enables lateral investigations and at various depths, that is, a two-dimensional product.

Five lines of electrical tomography were conducted with individual length of $120 \mathrm{~m}, 5 \mathrm{~m}$ spacing between electrodes, and readings at 12 levels of investigation in depth. The Terrameter SAS 4000 resistivity meter, manufactured by ABEM (Sweden), which consists in a single transmission and reception system, calibrated in field to injection of $100 \mathrm{~mA}$ current was used.

The arrangement of lines in the study area emphasized the proximity of drains emission biogas in an attempt to review the resistivity in their respective areas of influence (Figure 1).

The readings acquired in the field were processed in the Res2dinv program and resulted in sections of resistivity in terms of distance $\times$ depth, with graphical logarithmic scale and intervals of interpolation of values in color. This is a program that automatically determines a two-dimensional model of the subsurface, from resistivity or chargeability data obtained from tests of resistivity routing [26].

The $2 \mathrm{D}$ model used in the program divides the pseudosection into rectangular blocks, which will represent the pseudo-section by the adjustment of field readings. This optimization aims to reduce the difference between the apparent resistivity values, calculated and read in the field, by adjusting the resistivity of the blocks model, whose difference is expressed by the RMS error [27].

In the postprocessed graphic product the nearest drains were positioned, individualized with their respective numbers, to which areas for draining of biogas in depth were demarcated, which serve as the basis for subsequent discussions.

\section{Results and Discussion}

The results of biogas flow were tabulated and presented in Table 1.

The wide variation in the readings of biogas can be attributed to the spacing of drains in different age areas of waste disposal, in addition to the complex dynamics of production and flow of the biogas in a context of temporal variation in porosity.

The routine for waste disposal in the cells consists in the release of waste in the operation front by pickup trucks, compaction by bulldozers, and covering with soil excavated during the opening of the cell (Figure 2). This process aims 
TABLE 1: Flows of biogas obtained by direct measurements in drains.

\begin{tabular}{lc}
\hline Drain & Flow $\left(\mathrm{m}^{3} / \mathrm{h}\right)$ \\
\hline 24 & 117 \\
25 & 93 \\
26 & 99 \\
27 & 84 \\
28 & 76 \\
29 & 37 \\
30 & 52 \\
31 & 86 \\
\hline
\end{tabular}

at rationalizing the available space for storage of waste and minimizing the time of air exposure.

The creation of successive overlapping levels of waste results in increased compressive load of the older material, with reduction in porosity, also provided by the processes of consumption of organic matter, converted into gases and liquids that often leave this system with consequent rearrangement of inert residues such as plastics and rubber.

Therefore, the occurrence of low biogas flows in drains is natural for older areas in landfills, in face of at the least availability of organic matter likely to degradation and due to leakage of gas caused by fractures in the soil due to the rearrangement of waste, among other factors.

Regardless of the reasons, this huge variation in the readings of biogas shall be detectable in the areas of influence of the drains, because high electrical resistivity values are expected for areas where there is greater accumulation or flow of gases in a mass of solid waste. In contrast, areas enriched in organic matter shall be characterized by low resistivity values due to the relatively higher levels of moisture and dissolved salts. The early phase of anaerobic degradation is characterized by the generation of organic acids, which contribute to the decrease in electrical resistivity of this environment [18].

The spacing between electrodes and the number of levels investigated in depth resulted in sections molded for a depth of approximately $10 \mathrm{~m}$, interval considered as dry or unsaturated leachate, based on data obtained from drilling for waste layers in positions of lower topography.

The cross checking of flow and area of influence of the respective drain set to a radius of $10 \mathrm{~m}$ indicate the existence of predominantly resistive zones for the drains of greater flow, in contrast to areas of low resistivity in the vicinity of drains of low flow (Figure 3).

The drain 27 presents one of the highest flows of biogas in the studied area and its area of influence high resistivity for the line 1 and low resistivity for the line 4 . In contrast, the drain 29 presented the lowest flow and is positioned in an area of low resistivity, with values between $0 \Omega \cdot \mathrm{m}$ and $2000 \Omega \cdot \mathrm{m}$.

Some drains with intermediate flows feature in depth a high contrast in resistivity values in their areas of influence. Drains 26 and 31, with flow rates of $99 \mathrm{~m}^{3} / \mathrm{h}$ and $86 \mathrm{~m}^{3} / \mathrm{h}$, respectively, are positioned in the center of a high resistivity interface that varies laterally abruptly to low values of resistivity. Something similar occurs in depth in drain areas 25 ,
28,29 , and 30 , although in these cases the contrast interface is vertical.

In these cases they may be indicative of areas of degradation of organic matter and biogas production (low resistivity) neighbors to zones enriched in inert material and with porosity for accumulation of biogas (high resistivity). In this sense, the positioning of the drain in relation to areas of accumulation of biogas can condition the flow in surface.

The drain 24 crosses exactly an interval of high resistivity (between $8000 \Omega \cdot \mathrm{m}$ and $100.000 \Omega \cdot \mathrm{m}$ ), bordered by two smaller areas with resistivity between $2000 \Omega \cdot \mathrm{m}$ and $8000 \Omega \cdot \mathrm{m}$, which shall represent areas of accumulation and production of biogas, respectively. Drains with intermediate flows intersect partially in intervals of high resistivity or accumulation of biogas. Two perpendicular lines intersected the drain 29 and in both cases with low resistivity values, between $9.5 \Omega \cdot \mathrm{m}$ and $2000 \Omega \cdot \mathrm{m}$, indicative of an area with organic matter in degradation phase.

Line 3 crosses, respectively, the drains with lower and higher flow for the area of study. Between the drains there is a highly resistive interval, partially connected in depth to the drain of higher flow.

\section{Conclusions}

Readings in the drains describe a wide variation in biogas flow in a relatively small area, possibly due to issues such as age of the residues, compacting, constructive profile of drains, clogging, and connection among areas of accumulation of biogas and area of influence of the drains.

This latter aspect was subject to evaluation by means of the analysis of electrical resistivity readings for various levels of depth along lines of drains. Biogas is characterized as an electrical insulator in face of its physical state, that is, areas where there is accumulation of biogas as part of the waste mass must be characterized by high resistivity values. As counterpart, the generation of biogas in landfills with high amount of organic matter and high humidity results in low values of electrical resistivity.

The existence of zones of high resistivity (above $8000 \Omega \cdot \mathrm{m})$ in the catchment area of biogas around some drains in depth is reflected at the surface by high flow $\left(117 \mathrm{~m}^{3} / \mathrm{h}\right)$. Drains with intermediate flow rates $\left(65 \mathrm{~m}^{3} / \mathrm{h}\right.$ to $99 \mathrm{~m}^{3} / \mathrm{h}$ ) present concomitance in depth in domains of medium electrical resistivity (between $2000 \Omega \cdot \mathrm{m}$ and $8000 \Omega \cdot \mathrm{m}$ ); that is, the catchment area of the drain intersects zones of generation and accumulation of biogas. Drains with low flow $\left(37 \mathrm{~m}^{3} / \mathrm{h}\right.$ to $\left.52 \mathrm{~m}^{3} / \mathrm{h}\right)$ intersect in depth areas with low resistivity values (below $2000 \Omega \cdot \mathrm{m}$ ), associated with the predominance of areas of accumulation of organic matter and consequent generation of biogas.

The way for treatment of the data impairs the selection of specific values of electrical resistivity for comparison with other areas of study. Inversion of the data followed by the adoption of a logarithmic scale aimed at the enhancement of maximum and minimum in an attempt to highlight extreme domains; that is, the values resulting from processing extrapolate the range of input values in the program. 


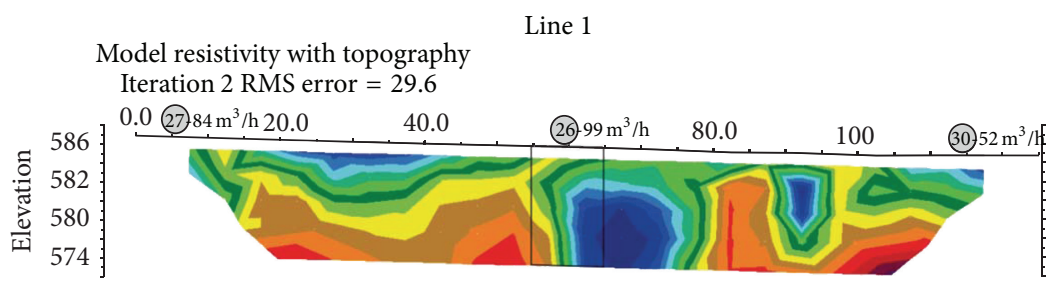

(a)

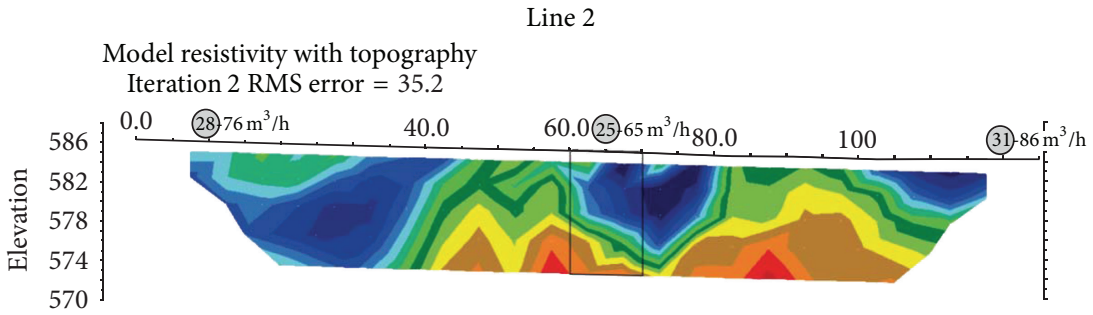

(b)

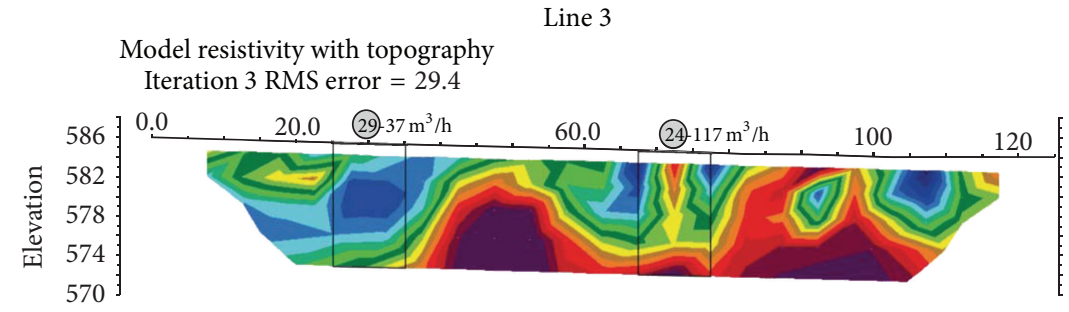

(c)

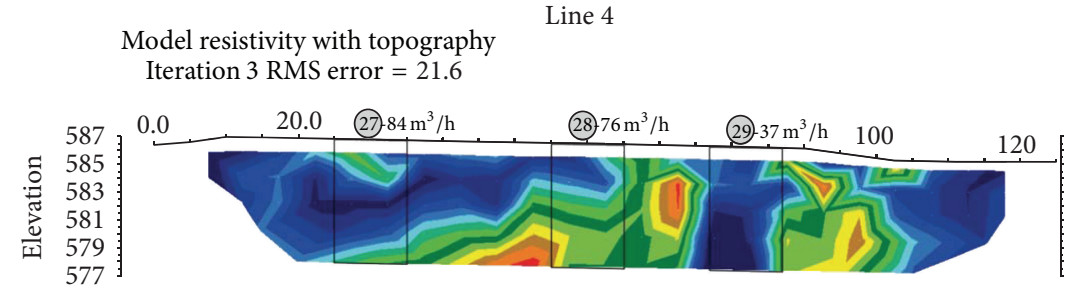

(d)

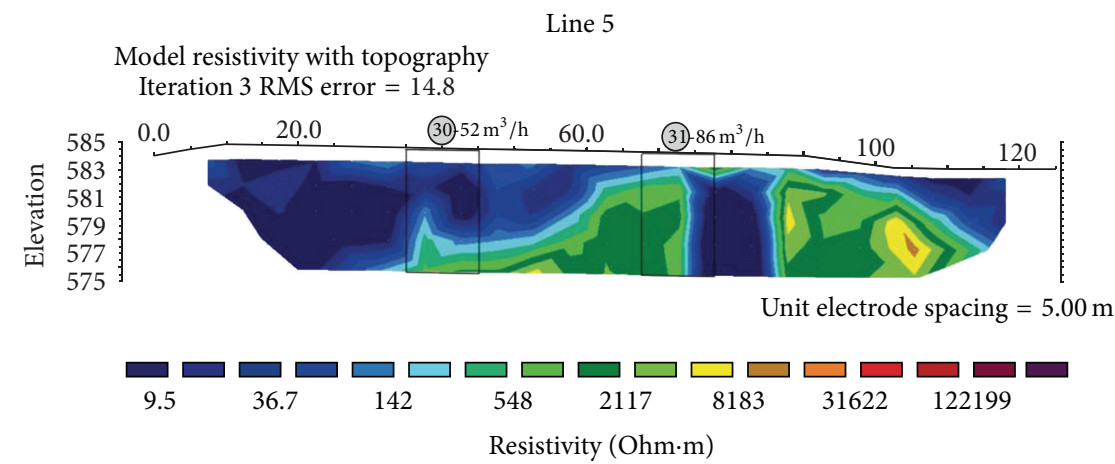

Horizontal scale is 47.52 pixels per unit spacing

Vertical exaggeration in model section display $=1.36$

First electrode is located at $0.0 \mathrm{~m}$

Last electrode is located at $125.0 \mathrm{~m}$

(e)

FIGURE 3: Models of inversion in terms of resistivity, position of biogas drains on the surface, and delineation of areas of influence in depth. 
However, the study demonstrates direct relationships between electrical resistivity in horizons of dry residues and biogas flow in drains installed throughout the period of residue cells filling at a landfill.

Such results suggest the feasibility of using electrical resistivity as an auxiliary tool in the investigation of suitable sites for catchment of biogas in the context of energetic use enterprises in sanitary landfills in the planning stage or in activity.

\section{Conflict of Interests}

The authors declare that there is no conflict of interests regarding the publication of this paper.

\section{References}

[1] CETESB/SMA, Biogás: Pesquisa e Projetos No Brasil, CETESB/ SMA, São Paulo, Brazil, 2006.

[2] Intergovernmental Panel on Climate Change-IPCC, Guidelines for National Greenhouse Inventories: Reference Manual, vol. 3, 1996.

[3] USEPA, A Guide for Methane Mitigation Projects: Gas to Energy at Landfills and Open Dumps, USEPA, Washington, DC, USA, 1996.

[4] M. J. Laquidara, A. P. Leuschner, and D. L. Wise, "Procedure for determining potential gas quantities in an existing sanitary landfill," Water Science and Technology, vol. 18, no. 12, pp. 151$162,1986$.

[5] G. Tchobanoglous, H. Theisen, and S. Vinil, Integrated Solid Waste Management. Engineering Principles and Management Issues, Irwin MacGraw-Hill, New York, NY, USA, 1993.

[6] J. Oonk and A. Boon, Landfill Gas Formation, Recovery and Emissions, Institute of Environmental and Energy Technology (TNO), Apeldoorn, The Netherlands, 1995.

[7] V. A. Ensinas, Estudo da Geração de Biogás no Aterro Sanitário Delta de Campinas-SP, Dissertações de Mestrado, Faculdade de Engenharia Mecânica-Universidade Estadual de CampinasUNICAMP, Campinas, Brazil, 2003.

[8] M. C. A. A. Castro and P. P. G. Bello, "Evaluation of percentage of methane gas generated in the landfill of the Rio Claro city, Brazil: study of energetic potential," in Proceedings of the $3 \mathrm{rd}$ International Symposium on Energy from Biomass and Waste, vol. 1, Venice, Italy, 2010.

[9] A. L. Lago, V. R. Elis, W. R. Borges, and G. C. Penner, "Geophysical investigation using resistivity and GPR methods: a case study of a lubricant oil waste disposal area in the city of Ribeirão Preto, São Paulo, Brazil," Environmental Geology, vol. 58, no. 2, pp. 407-417, 2009.

[10] A. M. Menezes, C. A. Moreira, L. M. Ilha, and C. Schweig, "Estudo geofísico de vazamento de combustíveis em posto de abastecimento," Geociências, vol. 30, pp. 491-500, 2011.

[11] V. Shevnin, O. Delgado-Rodríguez, A. Mousatov, and A. Ryjov, "Estimation of hydraulic conductivity on clay content in soil determined from resistivity data," Geofisica Internacional, vol. 45, no. 3, pp. 195-207, 2006.

[12] E. I. Okoro, B. C. E. Egboka, and A. G. Onwuemesi, "Evaluation of the aquifer characteristic of Nanka sands using hydrogeological method in combination with Vertical Electrical Sounding (VES)," Journal Applied Environmental Management, vol. 149, no. 2, pp. 5-9, 2010.
[13] C. C. Ezeh, G. Z. Ugwu, A. Okonkwo, and J. Okamkpa, "Using the relationships between geoelectrical and hydrogeological parameters to assess aquifer productivity in Udi LGA, Enugu State, Nigeria," International Research Journal of Geology and Mining, vol. 3, pp. 9-18, 2013.

[14] A. T. Ustra, V. R. Elis, G. Mondelli, L. V. Zuquette, and H. L. Giacheti, "Case study: a 3D resistivity and induced polarization imaging from downstream a waste disposal site in Brazil," Environmental Earth Sciences, vol. 66, no. 3, pp. 763-772, 2012.

[15] C. Augusto Moreira, A. Celso de Oliveira Braga, L. Hirata Godoy, and D. de Sousa Sardinha, "Relationship between age of waste and natural electric potential generation in Sanitary Landfill," Geofisica Internacional, vol. 52, no. 4, pp. 375-383, 2013.

[16] C. C. Okpoli, "Application of 2D electrical resistivity tomography in landfill site: a case study of Iku, Ikare Akoko, Southwestern Nigeria," Journal of Geological Research, vol. 2013, Article ID 895160, 8 pages, 2013.

[17] C. A. Moreira, A. C. D. O. Braga, and M. Fries, "Degradação de resíduos e alterações na resistividade elétrica, pH e Eh," Revista Brasileira de Geofísica, vol. 27, no. 2, pp. 283-293, 2009.

[18] I. Georgaki, P. Soupios, N. Sakkas et al., "Evaluating the use of electrical resistivity imaging technique for improving $\mathrm{CH}_{4}$ and $\mathrm{CO}_{2}$ emission rate estimations in landfills," Science of the Total Environment, vol. 389, no. 2-3, pp. 522-531, 2008.

[19] C. A. Moreira, A. C. de Oliveira Braga, and M. A. F. Hansen, "Time estimative of the leachate production in control landfill by electrical resistivity measuring," Revista Brasileira de Geociencias, vol. 41, no. 3, pp. 549-557, 2011.

[20] F. G. Pohland and J. P. Gould, "Co-disposal of municipal refuse and industrial waste sludge in landfills," Water Science and Technology, vol. 18, no. 12, pp. 177-192, 1986.

[21] N. J. Themelis and P. A. Ulloa, "Methane generation in landfills," Renewable Energy, vol. 32, no. 7, pp. 1243-1257, 2007.

[22] O. C. Gotardo, Estudo da relação tempo de aterramento de resíduos e vazão dos gases no aterro sanitário de Rio Claro$S P$, Monografia (Graduação), Universidade Estadual Paulista UNESP, 2013.

[23] E. Orellana, "Prospeccion Geoelectrica en Corriente Continua," Biblioteca Técnica Philips, Paraninfo, Madrid, Spain, 1972.

[24] W. M. Telford, L. P. Geldart, and R. E. Sheriff, Applied Geophysics, Cambridge University Press, New York, NY, USA, 2004.

[25] G. V. Keller and F. C. Frischknecht, Electrical Methods in Geophysical Prospecting, Pergamon Press, New York, NY, USA, 1966.

[26] D. H. Griffiths and R. D. Barker, "Two-dimensional resistivity imaging and modelling in areas of complex geology," Journal of Applied Geophysics, vol. 29, no. 3-4, pp. 211-226, 1993.

[27] M. H. Loke and R. D. Barker, "Rapid least-squares inversion of apparent resistivity pseudosections by a quasi-Newton method," Geophysical Prospecting, vol. 44, no. 1, pp. 131-152, 1996. 

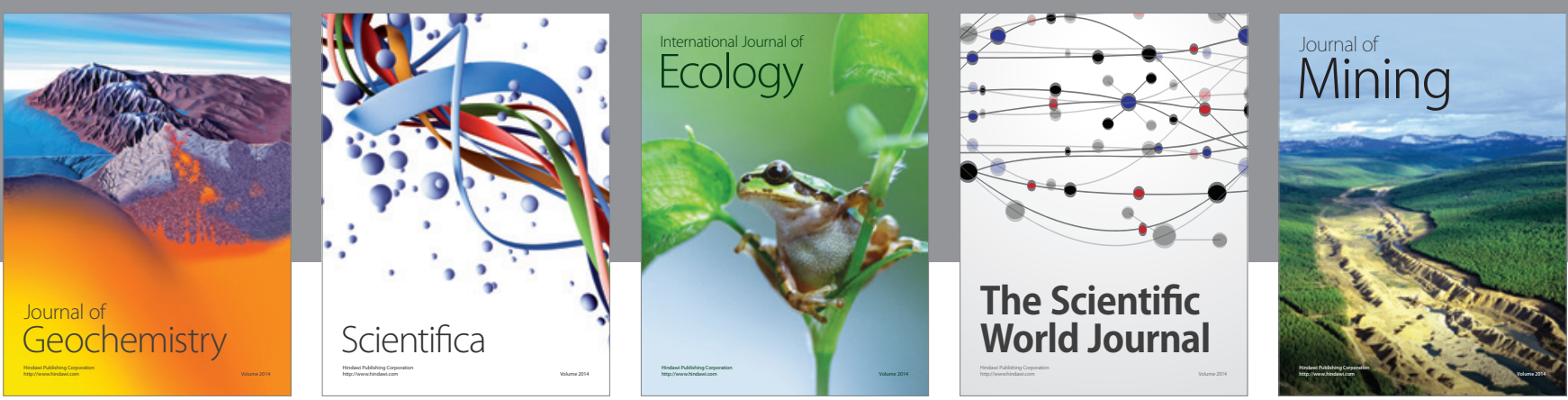

The Scientific World Journal
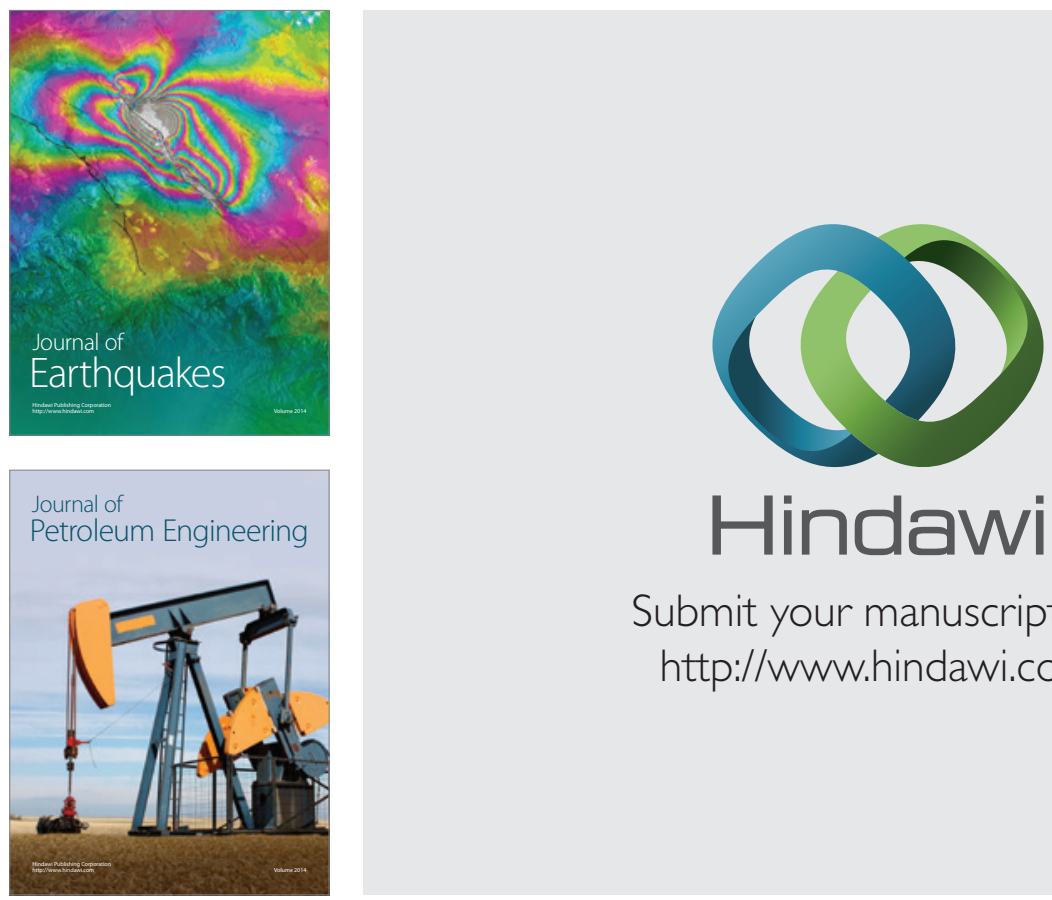

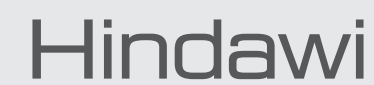

Submit your manuscripts at

http://www.hindawi.com
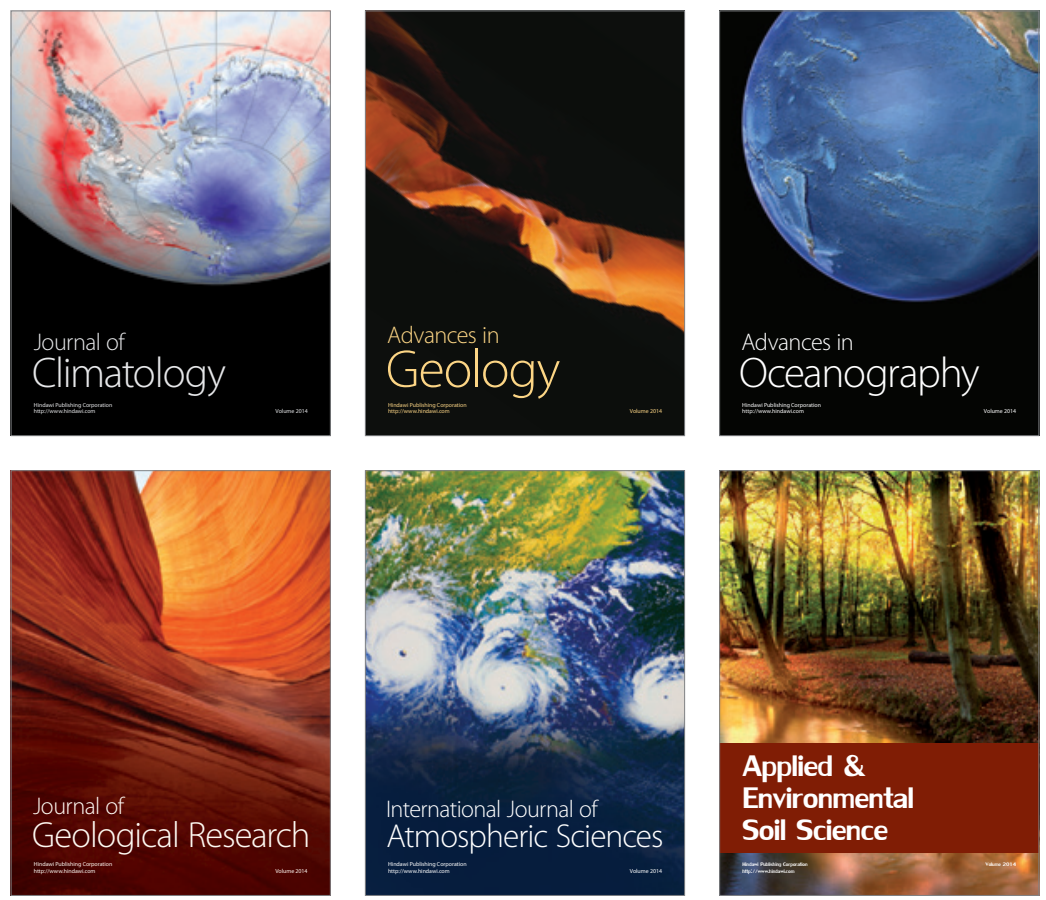
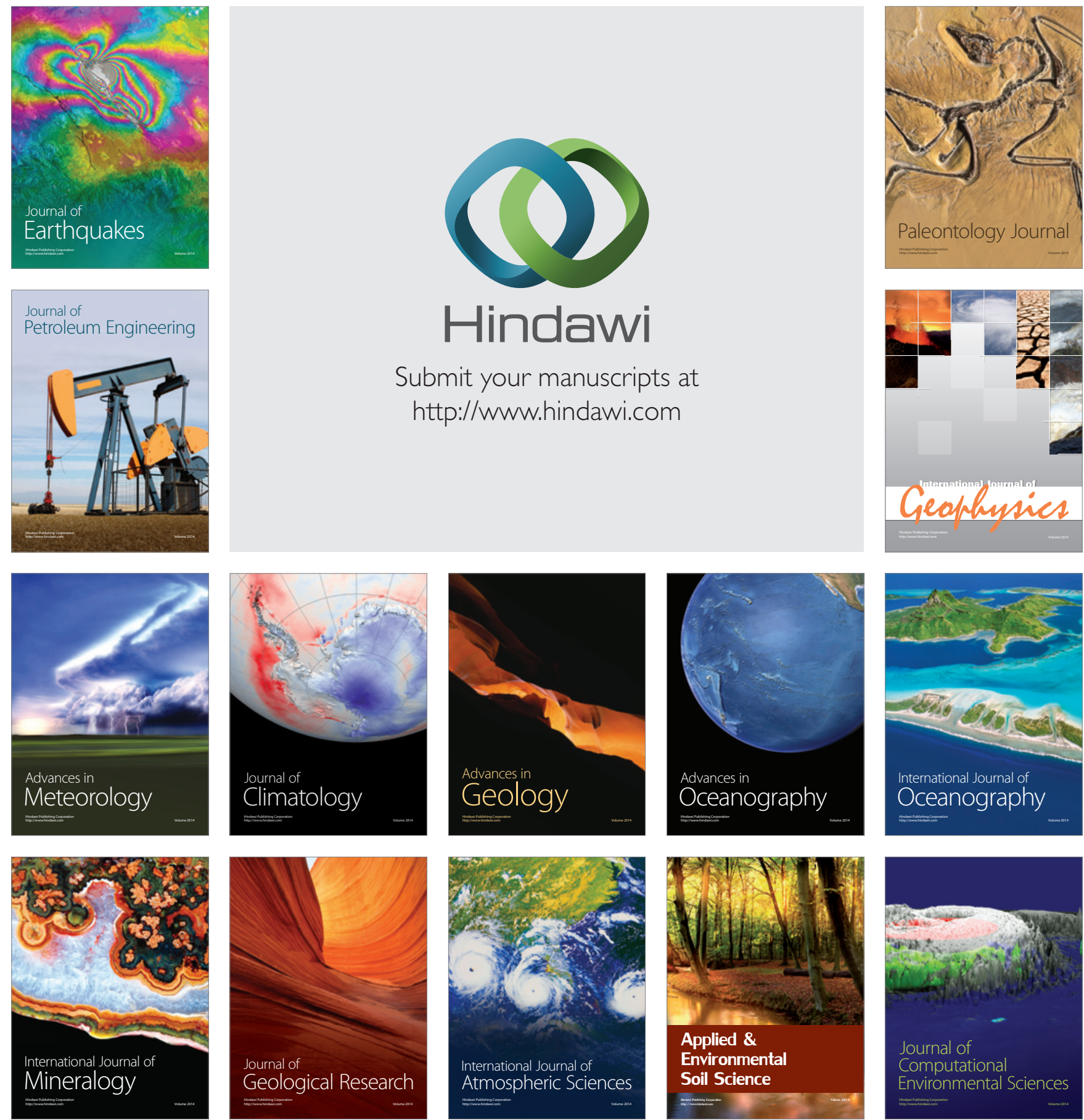